\title{
Mechanisms of TRH-induced GH Release (Paradoxical Response) in Human Somatotroph Adenoma Cells
}

\author{
HIROKO OKINAGA, KOJI TAKANO, SHUHEI HAYASHI, JUNKO YASUFUKU-TAKANO, \\ AKIRA TERAMOTO* AND TOSHIRO FUJITA \\ Department of Nephrology and Endocrinology, University of Tokyo Faculty of Medicine, 7-3-1 Hongo, Bunkyo-ku, Tokyo 113-8655, \\ Japan \\ *Department of Neurosurgery, Nippon Medical School, 1-1-5 Sendagi, Bunkyo-ku, Tokyo 113-8603, Japan
}

\begin{abstract}
The mechanisms of paradoxical TRH response in human somatotroph adenoma cells were investigated using intracellular calcium measurement and static incubation assay. Intracellular calcium measurement revealed that TRH induces a biphasic response: a transient increase followed by a sustained plateau. The transient phase was due to the calcium release from $\mathrm{IP}_{3}$-regulated intracellular calcium store and the subsequent sustained phase was due to the calcium influx through the voltage-gated calcium channels. The signal transduction mechanism of the calcium plateau involved protein kinase C. These calcium responses, especially the second phase, was responsible for the TRH-induced GH release.
\end{abstract}

Key words: Paradoxical response, TRH, Somatotroph adenoma cell, PKC, GH secretion

(Endocrine Journal 52: 763-767, 2005)

TRH stimulation test is clinically used to diagnose acromegaly or gigantism [1]. In about $40 \%$ of these patients TRH stimulation test shows paradoxical GH increase [2]. This test is also used to verify the total resection of the GH-secreting tumor and to detect regrowth of the adenoma after surgical resection. It is known that GH-secreting adenomas that show paradoxical response express TRH receptors [3-6]. However, the mechanisms of action of TRH have yet to be studied. In this study, we investigated the mechanism of action of TRH on GH-secreting human pituitary adenoma cells by measurement of intracellular calcium concentration $\left(\left[\mathrm{Ca}^{2+}\right]_{\mathrm{i}}\right)$ and static incubation assay.

Received: August 24, 2005

Accepted: September 1, 2005

Correspondence to: Koji TAKANO, M.D., Ph.D., Department of Nephrology and Endocrinology, University of Tokyo Faculty of Medicine, 7-3-1 Hongo, Bunkyo-ku, Tokyo 113-8655, Japan

\section{Materials and Methods}

\section{Drugs}

TRH was purchased from Peninsula (Belmont, CA, USA). Nitrendipine was purchased from Sigma (St. Louis, MO, USA), xestospongin $\mathrm{C}$ and calphostin $\mathrm{C}$ from Calbiochem (San Diego, CA). Diapase was purchased from Godo Shusei Co., Ltd. (Tokyo, Japan). Fura 2/AM was purchased from Molecular Probes (Eugene, OR).

\section{Cell preparation}

GH-secreting pituitary adenomas were obtained with informed consent from three patients operated for GHsecreting pituitary adenoma by transsphenoidal surgery (patients 1-3). This study and the use of human pituitary tissues resected at surgery as experimental materials is permitted by the Ethical Committee of University of Tokyo Faculty of Medicine. Preoperative serum GH levels of these patients were $5.8 \mathrm{ng} / \mathrm{ml}$ in patient 1 , $10.2 \mathrm{ng} / \mathrm{ml}$ in patient 2 , and $12.3 \mathrm{ng} / \mathrm{ml}$ in patient 3 . All 
these patients showed paradoxical GH increase by TRH test, and peak GH value after TRH administration was $13.5 \mathrm{ng} / \mathrm{ml}$ in patient $1,22.0 \mathrm{ng} / \mathrm{ml}$ in patient 2 , and $28.5 \mathrm{ng} / \mathrm{ml}$ in patient 3 . The adenoma tissues were minced into small pieces $(<1 \mathrm{~mm})$ and were digested with $1000 \mathrm{U} / \mathrm{ml}$ dispase. For investigating the hormonal release, cells were seeded on 24-well dishes at a density of $1 \times 10^{5}$ cells/well. For $\left[\mathrm{Ca}^{2+}\right]_{\mathrm{i}}$ measurements, cells were seeded on $22 \mathrm{~mm}$ round cover glasses and placed in $35 \mathrm{~mm}$ culture dishes. Cells were cultured in Dulbecco's modified Eagle's medium (DMEM) containing 10\% heat-inactivated fetal calf serum (FCS), and kept in humidified air containing $5 \% \mathrm{CO}_{2}$ at $37^{\circ} \mathrm{C}$. All experiments were carried out using cells cultured for 1 to 2 weeks.

\section{$\left[\mathrm{Ca}^{2+}\right]_{i}$ measurement}

Cells were loaded with fura 2 by incubating with $2 \mu \mathrm{M}$ fura 2/AM in Hanks' balanced salt solution containing $0.1 \%$ bovine serum albumin for $40 \mathrm{~min}$ at room temperature. $\left[\mathrm{Ca}^{2+}\right]_{\mathrm{i}}$ measurements were performed on a Nikon Diaphot microscope (Nikon, Tokyo, Japan). Each cell was excited at $340 \mathrm{~nm}$ and $380 \mathrm{~nm}$ alternately at a frequency of $100 \mathrm{~Hz}$ with CAM220 (Jasco, Tokyo, Japan). A band filter was used to monitor the fluorescent emission at $510 \mathrm{~nm}$. The cytosolic free $\mathrm{Ca}^{2+}$ concentration was determined from the equation $\left[\mathrm{Ca}^{2+}\right]_{\mathrm{i}}=\mathrm{K}\left(\mathrm{R}-\mathrm{R}_{\min }\right) /\left(\mathrm{R}_{\max }-\mathrm{R}\right)$ [7]. In this equation, $\mathrm{K}$ represents $\mathrm{Kd}\left(\mathrm{F}_{\min } / \mathrm{F}_{\max }\right)$, where $\mathrm{Kd}$ is the dissociation constant of fura $2\left(130 \mathrm{nM}\right.$ at $\left.25^{\circ} \mathrm{C}\right)$, and $\mathrm{F}_{\max } / \mathrm{F}_{\text {min }}$ is the ratio of $\mathrm{Ca}^{2+}$-free and $\mathrm{Ca}^{2+}$-bound fura 2 fluorescence at $380 \mathrm{nM} . R_{\min }$ is the $340 / 380$ fluorescence ratio of $\mathrm{Ca}^{2+}$-free fura 2 , and $\mathrm{R}_{\max }$ is the $340 / 380$ ratio of $\mathrm{Ca}^{2+}$-bound fura 2. Calibration was performed on every cell by permeabilizing the cell to $\mathrm{Ca}^{2+}$ with $2 \mu \mathrm{M}$ digitonin. Cells were first permeabilized in $\mathrm{Ca}^{2+}$-free saline $(5 \mathrm{mM}$ EGTA, $150 \mathrm{mM} \mathrm{KCl}$, and $10 \mathrm{mM}$ HEPES, $\mathrm{pH}=7.2$ ), for determination of $\mathrm{R}_{\min }$ and $\mathrm{F}_{\text {min }}$, and then in high $\mathrm{Ca}^{2+}$ saline $\left(2.5 \mathrm{mM} \mathrm{CaCl}_{2}, 150 \mathrm{mM}\right.$ $\mathrm{KCl}$, and $10 \mathrm{mM}$ HEPES, $\mathrm{pH}=7.4$ ) for determination of $\mathrm{R}_{\max }$ and $\mathrm{F}_{\max }$. The traces shown in the figures were filtered with a bandwidth of $1 \mathrm{~Hz}$ in order to reduce the noise. The standard external solution was as follows (in $\mathrm{mM}$ ): $128 \mathrm{NaCl}, 5 \mathrm{KCl}, 1 \mathrm{MgCl}_{2}, 2.5 \mathrm{CaCl}_{2}$, and 10 HEPES (Na salt, pH 7.4). $\mathrm{Ca}^{2+}$-free external solution was made by replacing $\mathrm{CaCl}_{2}$ in the standard solution with isoosmotic $\mathrm{NaCl}$. Other changes in the composition of the external solutions are noted. A peristaltic pump was used to perfuse the external solution during the experiment. Agonists were applied by changing the perfusing solution. About $30 \mathrm{sec}$ was necessary to change the bath solution in this system.

\section{Static incubation experiment}

Adenoma cells cultured in 24-well dishes were washed twice with serum-free DMEM containing $0.1 \%$ BSA. They were incubated with the same medium containing $100 \mathrm{nmol} / \mathrm{L}$ TRH for $2 \mathrm{hr}$ with or without $5 \mu \mathrm{M}$ nitrendipine. Some cells were pretreated with $1 \mu \mathrm{mol} / \mathrm{L}$ calphsotin $\mathrm{C}$, a PKC inhibitor, for $30 \mathrm{~min}$. After staurosporine pretreatment, cells were treated with or without $100 \mathrm{nmol} / \mathrm{L}$ TRH for $2 \mathrm{hr}$. After the incubation with various agents, the solution was collected and stored at $-20^{\circ} \mathrm{C}$ until the hormonal assay. $\mathrm{GH}$ was assayed using a radioimmunometric assay kit (Daiichi Radioisotope Laboratories, Tokyo, Japan).

\section{Cell identification}

At an early stage of the experiments, the cells were stained against human $\mathrm{GH}$ immunocytochemically to identify GH-secreting adenoma cells. Adenoma cells $(\mathrm{n}=7)$ that showed $\left[\mathrm{Ca}^{2+}\right]_{\mathrm{i}}$ increase to TRH application were fixed by $2 \%$ formaldehyde in phosphate buffer and stained for human $\mathrm{GH}$ by using a human $\mathrm{GH}$ immunostaining kit (DAKO Co., Ltd.; Glostrup, Denmark). All these cells stained positive for GH. In the subsequent experiments, data were obtained from cells which satisfied the criteria for pituitary adenoma cells obtained from our experience, which are roundshaped cells with a diameter of 10-20 $\mu \mathrm{m}$ which have smooth glittering surface under scanning light microscope. These characteristics were apparently different from those of the spindle-shaped fibroblast-like cells that grew in the adenoma cell culture.

\section{Results}

\section{$\left[\mathrm{Ca}^{2+}\right]_{i}$ response by $\mathrm{TRH}$}

Application of $1 \mathrm{nM}$ TRH induced a biphasic $\left[\mathrm{Ca}^{2+}\right]_{\mathrm{i}}$ response in these cells (Fig. 1A) in the standard extracellular solution $(\mathrm{n}=10)$. The peak of the first phase was $285 \pm 38 \mathrm{nmol} / \mathrm{L}(\mathrm{n}=10)$ and the plateau was $143 \pm 23 \mathrm{nmol} / \mathrm{L}(\mathrm{n}=10)$. Washout of TRH from the 

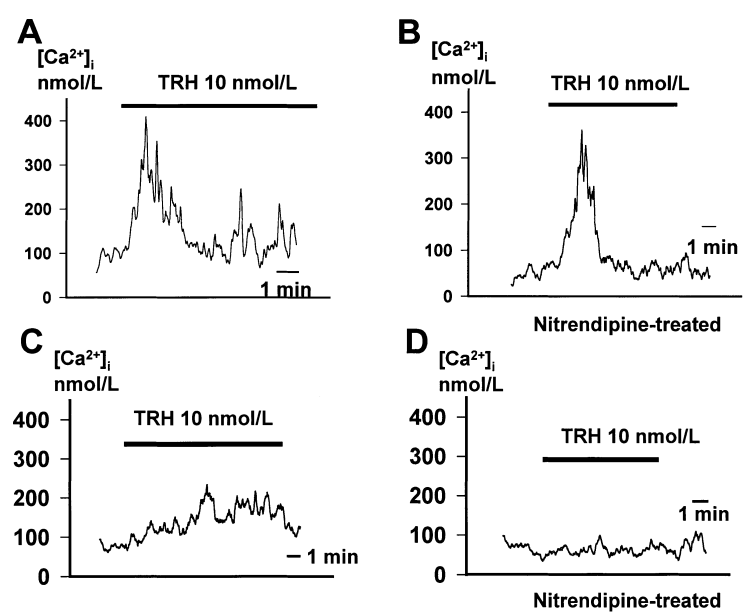

Fig. 1. TRH-induced $\left[\mathrm{Ca}^{2+}\right]_{\mathrm{i}}$ response in $\mathrm{GH}$-secreting adenoma cells. Application of $10 \mathrm{nmol} / \mathrm{L}$ TRH induced twophase $\left[\mathrm{Ca}^{2+}\right]_{i}$ response in the standard external solution (A). The second sustained phase was diminished in external solution containing $1 \mu \mathrm{mol} / \mathrm{L}$ nitrendipine (B). In a cell from adenoma 3, TRH evoked a slow plateau response $(\mathrm{C})$. The plateau resoponse was abolished in the extracellular solution containing nitrendipine (1 $\mu \mathrm{mol} / \mathrm{L}$ ) (D).

external solution reversed the plateau. When TRH was applied to the cell in external solution containing nitrendipine $(1 \mu \mathrm{mol} / \mathrm{L})$, the biphasic response was no longer observed but resulted in a transient monophasic response (Fig. 1B). Similar monophasic peak was observed in 5 other cells of adenoma 1 and 6 cells of adenoma 2. The monophasic response corresponded to the first peak of the biphasic response. Depletion of extracellular $\mathrm{Ca}^{2+}$ from the external solution also resulted in a monophasic response to TRH application (data not shown). These data indicate that the second plateau was dependent on the calcium influx through the voltage-gated calcium channels (mainly L-type channels). In cells of adenoma 3, TRH induced a sustained plateau response (Fig. 1C). The sustained response was observed in most of the cells $(n=8)$ in adenoma 3 except for one cell that exhibited the biphasic response. The plateau response was abolished in external solution containing nitrendipine $(1 \mu \mathrm{mol} / \mathrm{L})$ (Fig. 1D) Similar results were observed in 5 other cells in adenoma 3.

To analyze the nature of the initial peak, xestospongin $\mathrm{C}$, a blocker of the IP3-induced calcium release was used. After 30 min incubation with xestospongine $\mathrm{C}(1 \mu \mathrm{mol} / \mathrm{L})$, the TRH-induced response became a gradual plateau (Fig. 2A) in 5 out of 5 cells of
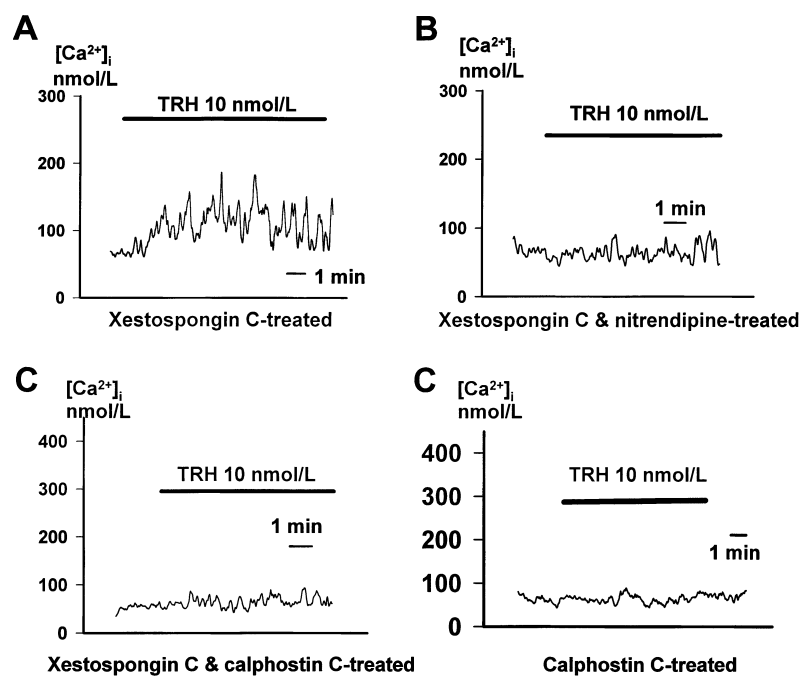

Fig. 2. In a cell from adenoma 1 that was pretreated with xestospongin $\mathrm{C}(1 \mu \mathrm{mol} / \mathrm{L}$ for $30 \mathrm{~min})$, TRH evoked a monophasic plateau (A). After pretreatment with xestospongin $\mathrm{C}$, another cell was applied with TRH in external solution containing nitrendipine $(1 \mu \mathrm{mol} / \mathrm{L})$. In this condition, both the first peak and second plateau were abolished (B). In a cell pretreated with xestospongin $\mathrm{C}$ and calphostin $\mathrm{C}$ the second plateau were significantly attenuated (C). In a cell of adenoma 3 , the slow plateau response was significantly attenuated by calphostin C pretreatment (D).

adenoma 1 and in 6 out of 6 cells of adenoma 2. When nitrendipine $(1 \mu \mathrm{mol} / \mathrm{L})$ was involved in the external solution after pretreatment with xestospongine $\mathrm{C}$, both the first peak and second plateau disappeared (Fig. 2B) in 5 out of 5 cells of adenoma 1 and in 6 out of 6 cells of adenoma 2. These data indicate that the first peak was due to the calcium release from $\mathrm{IP}_{3}$-dependent calcium store, and that the sustained phase dependent on calcium influx through L-type channels.

The involvement of PKC in the second phase (sustained plateau) was investigated in the next experiment. After blocking the initial phase with xestospongin $\mathrm{C}(1 \mu \mathrm{mol} / \mathrm{L})$, the cells were pretreated with a PKC inhibitor calphostin C $(1 \mu \mathrm{mol} / \mathrm{L}$ for $30 \mathrm{~min})$. In these cells, the sustained calcium response by TRH was significantly attenuated (Fig. 2C) in a cell of adenoma 1. The calcium concentration of the second phase was $122 \pm 14 \mathrm{nmol} / \mathrm{L}$ and was significantly reduced compared to the cells treated with xestospongin $C(n=5$, adenoma 2). In adenoma 3 , when the cells were pretreated with calphostin $\mathrm{C}(1 \mu \mathrm{mol} / \mathrm{L}$ for $30 \mathrm{~min})$, the sustained plateau response was significantly suppressed (Fig. 2D, $n=6$ ). These data indicate that some 
PKC is involved in the second sustained phase of the biphasic response and in the sustained response in adenoma 3.

\section{Static incubation study}

GH secretion from adenoma cells was measured by static incubation study to evaluate the role of TRHinduced calcium response in TRH-induced hormone secretion. Adenoma cells were incubated in external solution with or without nitrendipine $(1 \mu \mathrm{mol} / \mathrm{L})$, and the effect of TRH on GH secretion was examined. Fig. 3A shows the effects of TRH on GH secretion from cells of adenoma 1. TRH increased GH secretion in the standard external solution in a concentration dependent manner. The effect of TRH $(10 \mathrm{nmol} / \mathrm{L})$ was markedly reduced in external solutions containing nitrendipine. Similar results were obtained in adenoma 3 (Fig. 3B). The involvement of PKC in the TRH-induced GH release was investigated by the PKC inhibitor calphostin C. Pretreatment of the cells with calphostin C $(1 \mu \mathrm{mol} /$ $\mathrm{L}, 30 \mathrm{~min}$ ) attenuated TRH-induced $\mathrm{GH}$ secretion in adenoma 1 and adenoma 3 (Fig. 2A and 2B).
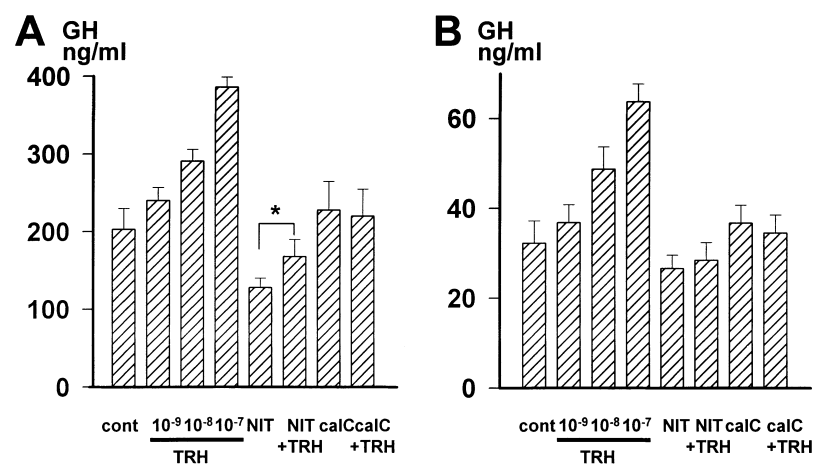

Fig. 3. TRH-induced GH secretion from cells of adenoma 1 (A) and adenoma 2 (B). "Cont" indicates GH secretion in control external medium, "TRH", in external medium containing TRH of indicated concentration (in $\mathrm{mol} / \mathrm{L}$ ), "NIT" in external medium containing $1 \mu \mathrm{mol} / \mathrm{L}$ nitrendipine, "NIT + TRH", in external medium containing $1 \mu \mathrm{mol} / \mathrm{L}$ nitrendipine and $10 \mathrm{nmol} / \mathrm{L} \mathrm{TRH}$, "calC", in external medium containing $1 \mu \mathrm{mol} / \mathrm{L}$ calphostin $\mathrm{C}$, "calC + TRH", in external medium containing $1 \mu \mathrm{mol} / \mathrm{L}$ calphostin $\mathrm{C}$ and $10 \mathrm{nmol} / \mathrm{L}$ TRH. Data are shown as mean \pm S.D. of data from four wells. Bar indicates 1 SD. The data in (A) and (B) were analyzed by one-way ANOVA and both data were found to be significantly different $(p<0.01)$. Difference between each pair was analyzed by post-test (Tukey) $(* \mathrm{P}<0.05)$. There was a significant concentration dependency in TRH-induced GH secretion in (A) and (B) that was confirmed by post test for linear trend.

\section{Discussion}

In this study, the mechanisms of paradoxical TRH response in human somatotroph adenoma cells were investigated using intracellular calcium measurement and static incubation experiment. TRH induced biphasic calcium response in these cells. The first transient peak was due to the calcium release from $\mathrm{IP}_{3}$-regulated calcium store. The second plateau was due to calcium influx mainly through L-type voltage-gated calcium channels. The static incubation study showed that the second phase was primarily responsible for $\mathrm{GH}$ release.

Human anterior pituitary cells are excitable cells [8] that generate action potentials at rest. Regulators of anterior pituitary hormone secretion, such as hypothalamic hormones, regulate hormone secretion by changing the excitability of anterior pituitary cells [911]. It is known that human GH-secreting adenoma cells express two types of voltage-gated calcium channels, namely L-type and T-type channels [12]. GHRH stimulates GH secretion by depolarizing the cells and increasing action potential firing to increase calcium influx through the L-type voltage-gated calcium channels [9]. In the present study, the second plateau calcium response by TRH was due to the calcium influx through the voltage-gated calcium channels (mainly L-type channels) that participated in TRH-induced $\mathrm{GH}$ secretion. In human TSH-secreting adenoma cells, TRH induces a biphasic electrophysiological response [13]. Transient hyperpolarization followed by a sustained depolarization. During the transient hyperpolarization, action potentials are blocked. During the sustained depolarization, the frequency of action potentials increases, suggesting a plateau calcium response during this phase. The present study suggested that similar electrophysiological responses are evoked by TRH in GH-secreting adenoma cells. The second plateau calcium response may be accompanied by an increase in action potential frequency. Electrophysiological studies are necessary to analyze this phenomenon further. The second plateau response was mediated through a PKC-dependent mechanism. The role of the first transient peak may be the facilitation of PKC-mediated response by rapidly increasing the intracellular calcium concentration.

The static incubation experiment revealed that TRHinduced GH secretion was dependent on the calcium influx through L-type voltage-gated calcium channels. The major role of calcium influx through the L-type 
voltage-gated calcium channels is also observed in the mechanism of somatostatin-induced inhibition of GH secretion [14]. PKC inhibitor attenuated the plateau phase calcium response. If TRH-induced GH secretion is mainly dependent on calcium influx through the voltage-gated calcium channels, the PKC inhibitor will also inhibit TRH-induced GH secretion. The static in- cubation experiment confirmed this speculation.

The present study revealed the calcium mechanisms of TRH-induced paradoxical response in GH-secreting adenomas. Further studies employing electrophysiological analyses may further deepen our understanding of the cellular events induced by TRH in these cells.

\section{References}

1. Irie M, Tsushima T (1972) increase of serum growth hormone concentration following Thyrotropin-releasing hormone injection in patients with acromegaly or gigantism. J Clin Endocrinol Metab 35: 97-100.

2. Harvey S (1990) Thyrotropin-releasing hormone: a growth hormone-releasing factor. J Endocrinol 125: 345-358.

3. Ehrchen J, Peters A, Lüdecke K, Visser T, Bauer K (2000) Analysis of thyrotropin - releasing hormonesignaling components in pituitary adenomas of patients with acromegaly. J Clin Endocrinol Metab 85: 27092713.

4. Kim K, Arai K, Sanno N, Teramoto A, Shibasaki T (2001) The expression of Thyrotropin-releasing hormone receptor 1 messenger ribonucleic acid in human pituitary adenomas. Clin Endocrinol 54: 309-316.

5. Kaji H, Xu Y, Abe H, Tamaki N, Chihara K (1995) Human TRH receptor messenger ribonucleic acid levels in normal and adenomatous pituitary: analysis by the competitive reverse transcription polymerase chain reaction method. Clin Endocrinol 42: 243-248.

6. Igarashi-Migitaka J, Yamada $\mathrm{S}$, Hara $\mathrm{M}$, Sano $\mathrm{T}$, Ozawa Y, Ohtani-Kaneko R, Hirata K (2003) Gene expression study of thyrotropin releasing hormone (TRH) receptor using RT-PCR: Relationship to clinical and immunohistochemical phenotypes in a series of human pituitary adenomas. Endcr J 50: 459-467.

7. Tsien RY (1980) New calcium indicators and buffers with high selectivity against magnesium and proteins: design, synthesis and properties of prototype structures.
Biochemistry 19: 2396-2404.

8. Ozawa S, Sand O (1986) Electrophysiology of excitable endocrine cells. Physiological Review 66: 887951.

9. Takano K, Takei T, Teramoto A, Yamashita N (1996) Growth hormone-releasing hormone activates a cation current in human growth hormone-secreting adenoma cells. Am J Physiol 270: E1050-E1057.

10. Takano K, Yasufuku-Takano J, Teramoto A, Fujita T (1996) Corticotropin-releasing hormone excites ACTHsecreting human pituitary adenoma cells by activating a nonselective cation current. J Clin Invest 98: 20332041.

11. Takano K, Asano S, Yamashita N (1994) Activation of $\mathrm{G}$ protein-coupled $\mathrm{K}^{+}$channels by dopamine in human GH-producing cells. Am J Physiol 266: E318-E325.

12. Yamashita N, Matsunaga H, Shibuya N, Teramoto A, Takakura K, Ogata E (1988) Two types of calcium channels and hormone release in human pituitary tumor cells. Am J Physiol 255: E137-E145.

13. Takano K, Ajima M, Teramoto A, Hata K, Yamashita N (1995) Mechanisms of action of somatostatin on human TSH-secreting adenoma cells. Am J Physiol 268: E558-E564.

14. Yamashita N, Takano K, Teramoto A, Takakura K, Ogata E (1992) Simultaneous measurement of changes in the membrane potential and the intracellular $\mathrm{Ca}^{2+}$ concentration caused by somatostatin in human $\mathrm{GH}$ producing pituitary adenoma cells. Endocrinol Jpn 39: 491-497. 